\title{
Empirical Study on the Influences of Rural Land Circulation on Grain Security
}

\author{
$\mathrm{Xu}$ Jiajun ${ }^{1}$ and Wang Mingzhe ${ }^{2}$ \\ ${ }^{1}$ School of Public Administration, Hohai University, Nanjing, 211100, China \\ ${ }^{1}$ School of Public Administration, Hohai University, Nanjing, 211100, China \\ ${ }^{1}$ Xujiajun2004@126.com, ${ }^{2}$ mingzhewang88@163.com
}

\begin{abstract}
Focusing on the phenomenon that rural land circulation has translated farmland into non-agricultural and non-grain land in recent years, this paper tries to theoretically solve the significant practical issue of sharp reduction in farmland caused by urbanization and grain security that is badly in need of solution in China through constructing models to study the relations between rural land circulation and grain security. As an important part of national security, grain security is a key strategic issue concerning national economy and the people's livelihood. Grain security, energy security and financial security are called three major kinds of economic security in the world. In 2014, China's grain output reached 607.10 million tons, seeing increases for 11 consecutive times, but the self-sufficiency rate of grain reduced to under $90 \%$, and the grain supply gap continued to widen. To this end, the CPC Central Committee has proposed the new national grain security strategy of "Self-centered, state-based, capacity-guaranteed, and technology-supported with appropriate import" and taken important measures to strengthen land circulation and expand business scale. However, in theory, the issues whether agricultural production has scale operation and whether scale operation can increase grain output have remained controversial for a long time. In reality, China's rural land circulation proportion in 2014 reached 28.8\%, but the phenomena of nongrain farmland and non-agricultural farmland become serious. Therefore, this paper shows significance in both theory and practice with regard to the study on the relations between China's grain security and rural land circulation as well as relevant policies. Through construction of Nerlove model of grain supply response, quantitative analysis is conducted to study the influences of rural land circulation on grain safety and relevant policies and suggestions are proposed in this paper.
\end{abstract}

Keywords: Rural land circulation; Grain security; Urbanization; Nerlove model

\section{Introduction}

From the perspective of the historical development of human society, land is the most important production factor. Along with the transformation of Chinese society from a traditional one to a modern one, the operation mode and use of land resources have changed correspondingly. In terms of operation mode, transformation from decentralized operation to intensive operation of a certain degree is an inevitable trend. Currently, China is at the stage of the second leap of agricultural development and reform, that is, China should meet the needs of scientific farming and socialization of production to develop moderate scale management and collective economy. This is great progress and certainly a long process. Regarding use, in the process of land resource allocation and evolution, some of the land use will surely change, especially the acceleration of modernization process, and transformation from rural land to urban construction land is another inevitable trend. 
Such a change is realized through rural land circulation. Certainly, a majority of Chinese and foreign scholars believe that this is one of the features of social progress to some extent, while from the perspective of grain production security, land circulation is bound to pose a great threat to grain security. On the one hand, modernization and urbanization are imperative. According to Ou Jian [1], land circulation is an inevitable trend of economic development and social transformation. On the other hand, grain security is an important part of national security and it is an issue that China must handle appropriately at the current state. In this context, how to prudently and normatively guide and promote reasonable rural land circulation is not only a significant theoretical issue but also an urgent practical issue.

Foreign studies on rural land circulation and grain security mainly focus on such aspects as rural land system, market-oriented land circulation, government intervention to land circulation, and influences of land circulation on grain security. Feder [2] proposes that rural land systems should include formal systems and informal systems. According to Exizabeth Brabec [3] and Chip Smith, rural land circulation man change the modes of land utilization, increase or decrease the scale of rural land and even change the structure of agricultural production. Macmilian [4] states that market failure may occur in the process of land transaction and governments should appropriately intervene in land circulation market to make up for the inadequacy of market regulation. Pardey [5] states that normalized land circulation system can enhance the rural land utilization efficiency. Alvarez [6] believes that land circulation has a significant influence on operation scale while improvement of agricultural scale operation and production efficiency is greatly affected by rural land fragmentation.

China has made great achievements in the study of rural land circulation and grain security, with the research areas mainly focusing on such three aspects as the relations between rural land circulation and grain security, the influences of rural land circulation on grain security, and countermeasure study concerning the "non-grain phenomenon" after rural land circulation. According to Zhang Yunhua [7]et. al., agricultural scale operation needs reasonable and normalized rural land circulation to realize reduction in unit production cost, enhancement of agricultural output capacity and increase in grain output and guarantee national grain security. Nie Liangpeng et. al., [8] propose that land circulation has facilitated scale production of grain, created conditions for the application of large-scale mechanization and promotion of new agricultural technology and new products, provided a platform for scientific field management and mechanized harvesting, enhanced the productive labor efficiency and improved the per unit area yield of grain, while low economic benefit of grain growing, serious "non-grain phenomenon" tendency and sharp decrease in the total grain-growing area have led to reduction in the gross output of grain and threatened grain security. Zhu Zhonggui [9] suggests applying systems that can strictly restrict land use changes, implementing corresponding legal means and exercising tight control over the "non-grain phenomenon" after rural land circulation. Zhang Wugang [10] proposes that we should increase input and subsidies through policies to enhance benefits of grain growing.

Chinese and foreign scholars have conducted in-depth studies on the influences of rural land circulation on grain security, but such studies mainly focus on qualitative analysis. As there is no relevant study on quantitative analysis through modeling, it is expected to build models for quantitative analysis in this aspect. In this paper, Nerlove model of grain supply response is constructed to quantitatively analyze the influences of rural land circulation on grain security so as to fill in the gaps in existing studies and provide useful reference for the policy suggestions on perfecting land circulation and ensuring national grain security.

\section{Materials and Methods}


In this paper, a grain output supply response model is constructed based on the Nerlove model to analyze the influences of rural land circulation on grain security. For the problems such as the correlation of residuals between variables, the generalized least squares (GLS) method is adopted in this paper to carry out regression so as to make random error terms eliminate auto-correlation. In addition, augmented Dickey-Fuller (ADF) unit root test and Johansen co-integration test are adopted to verify that the regression belongs to real regression.

\subsection{Nerlove Model}

Nerlove supply response model is a relatively mature and most widely applied model among the existing econometric models of agricultural supply response. Nerlove [11] used this theory for the first time to analyze the dynamic supply response of agricultural products, and some scholars made improvements to it in the research process according to different practical situations. The influences of this model and the combinatory analysis that utilizes production function according to a group of input factors on industries are different. Nerlove model supposes that peasant households adjust area (output) according to the expected price to respond to external stimulus and in the meantime takes the features of adaptive expectations and local adjustment theory into account. This model can be indicated as not only the crop output response but also the crop planting area response.

In this study, Nerlove model is applied in the grain crop output response. As the lagged terms of dependent variables and other explanatory variables are included in the model, Nerlove model is a dynamic auto-regression model. The key components of the model are as follows:

$$
\begin{aligned}
& A_{t}^{*}=\alpha_{0}+\alpha_{1} P_{t}^{*}+\alpha_{2} Z_{t}+\mu_{t} \\
& P_{t}^{*}=P_{t-1}^{*}+\beta\left(P_{t-1}-P_{t-1}^{*}\right)(0 \leq \beta \leq 1) \\
& A_{t}=A_{t-1}+\gamma\left(A_{t}^{*}-A_{t-1}\right)(0 \leq \gamma \leq 1)
\end{aligned}
$$

Among these components, $A_{t}$ and $A_{t}^{*}$ are respectively the actual output (or the actual sowing area) and the long-term equilibrium output (or the sowing area); $P_{t}$ and $P_{t}^{*}$ are respectively the actual price and expected prices at $t ; \beta$ and $\gamma$ respectively stand for the expected supply adjustment coefficient and the expected price adjustment coefficient; $Z_{t}$ refers to other external variable affecting the crop output or planting area in No. $\mathrm{t}$ year; $\mu_{t}$ is a random disturbance term.

$A_{t}^{*}$ and $P_{t}^{*}$ are unobservable variables. To effectively use the Nerlove supply response model, equations (1), (2) and (3) must be used to carry out computational elimination. The result after computation is:

$$
\begin{aligned}
& A_{t}=(\beta \gamma) \alpha_{0}+(\beta \gamma) \alpha_{1} P_{t-1}+(2-\beta-\gamma) A_{t-1}+(1-\beta)(1-\gamma) A_{t-2}+\gamma \alpha_{2} Z_{t}+\gamma \alpha_{2}(1-\beta) Z_{t-1}+ \\
& \quad \gamma \mu_{t}+\gamma(1-\beta) \mu_{t-1} \\
& \text { Suppose: } \mu_{t}=\rho \mu_{t-1}+e_{t}(-1<\rho<1) ; \\
& \quad \mathrm{E}(e)=0 ; \operatorname{cov}(e)=\sigma^{2} . \\
& \text { If }(\beta \gamma) \alpha_{0}=b_{0} ; \quad(\beta \gamma) \alpha_{1}=b_{1} ; \quad(2-\beta-\gamma)=b_{2} ; \quad(1-\beta)(1-\gamma)=b_{3} ; \gamma \alpha_{2}=b_{4} ; \\
& \gamma \alpha_{2}(1-\beta)=b_{5} ; \gamma \mu_{t}+\gamma(1-\beta) \mu_{t-1}=v, \text { then }(4) \text { is translated to: }
\end{aligned}
$$




$$
A_{t}=b_{0}+b_{1} P_{t-1}+b_{2} A_{t-1}+b_{3} A_{t-2}+b_{4} Z_{t}+b_{5} Z_{t-1}+v
$$

In the equation, $b_{1}$ is the short-term supply price elasticity needed, $\frac{b_{1}}{1-b_{2}-b_{3}}$ is the long-term price elasticity, and the coefficient of expectation is $\left(1-b_{2}-b_{3}\right)$.

\subsection{Generalized Least Square (GLS)}

Ordinary least square method and weighted least square method are special cases of GLS. The most common way of existing sequence correlation is GLS.

$$
\begin{aligned}
& Y=\left(\begin{array}{l}
y_{1} \\
y_{2} \\
\vdots \\
y_{n}
\end{array}\right) X=\left(\begin{array}{cccc}
1 & x_{11} & \cdots & x_{1 m} \\
1 & x_{21} & \cdots & x_{2 m} \\
\vdots & \vdots & & \vdots \\
1 & x_{n 1} & \cdots & x_{n m}
\end{array}\right) \quad B=\left(\begin{array}{l}
b_{0} \\
b_{1} \\
\vdots \\
b_{m}
\end{array}\right) U=\left(\begin{array}{l}
u_{1} \\
u_{2} \\
\vdots \\
u_{n}
\end{array}\right) \\
& E(U)=0 \\
& \Omega=\left(\begin{array}{cccc}
w_{11} & w_{12} & \cdots & w_{1 n} \\
\vdots & w_{22} & \cdots & \\
\vdots & & \vdots \\
w_{n 1} & w_{n 2} & \cdots & w_{n n}
\end{array}\right) \text { Heteroscadacity exists. }
\end{aligned}
$$

Given: $\Omega=D D^{\prime}$, let $D^{-1}$ be multiplied by $Y=X B+U$ on both sides

$$
\begin{aligned}
& D^{-1} Y=D^{-1} X B+D^{-1} U \text { i.e., } \\
& Y^{*}=X^{*} B+U^{*} \\
& \operatorname{cov}\left(U^{*} U^{*^{\prime}}\right)=E\left(U^{*} U^{*^{\prime}}\right)=E\left(D^{-1} U U^{\prime} D^{-1^{\prime}}\right) \\
& =D^{-1} E\left(U U^{\prime}\right) D^{-1^{\prime}} \\
& =D^{-1} \sigma^{2} \Omega D^{-1^{\prime}}=\sigma^{2} D^{-1} D D^{\prime} D^{-1^{\prime}} \\
& =\sigma^{2} I
\end{aligned}
$$

The result obtained through the least square method is:

$$
\begin{aligned}
& \hat{B}=\left(X^{*^{\prime}} X^{*}\right)^{-1} X^{*^{\prime}} Y^{*} \\
& =\left(X D^{-1} D^{-1} X\right)^{-1} X D^{-1} D^{-1} Y \\
& =\left(X^{\prime} \Omega^{-1} X\right)^{-1} X^{\prime} \Omega^{-1} Y
\end{aligned}
$$

This is the parameter estimator of the model estimated with the GLS method.

\subsection{Principle of ADF Test}

For the AR (p) process, if all characteristic roots in the characteristic equation are in the unit circle, array $\left\{x_{t}\right\}$ is stationary; if a characteristic root exists and is 1 , the array is very stationary and the sum of auto-regression coefficients exactly equals 1 . Proof is as follows: 


$$
\begin{aligned}
& \lambda^{p}-\phi_{1} \lambda^{p-1}-\cdots-\phi_{p}=0 \\
& \stackrel{\lambda=1}{\Rightarrow} 1-\phi_{1}-\cdots-\phi_{p}=0 \\
& \Rightarrow \phi_{1}+\phi_{2}+\cdots+\phi_{p}=1
\end{aligned}
$$

Therefore, for the AR (p) process, we can test the stationarity of the array by checking whether the sum of auto-regression coefficients equals 1 . The hypothesis testing is as follows:

$$
H_{0}: p=0 \leftrightarrow H_{1}: p<0 \text {, and } p=\phi_{1}+\phi_{2}+\cdots+\phi_{p}-1
$$

ADF test statistics: $\tau=\frac{p}{S(\hat{p})}$, wherein, $S(\hat{p})$ is the sample standard deviation of parameter $\mathrm{p}$.

There are three types of ADF test:

Type 1: a p-order auto-regression process that has no constant mean and trend: $x_{t}=\phi_{1} x_{t-1}+\cdots \phi_{p} x_{t-p}+\varepsilon_{t}$

Type 2: a p-order auto-regression process that has a constant mean and has no trend: $x_{t}=\mu+\phi_{1} x_{t-1}+\cdots \phi_{p} x_{t-p}+\varepsilon_{t}$

Type 3: a p-order auto-regression process that has a constant mean and a linear trend: $x_{t}=\mu+\beta \mathrm{t}+\phi_{1} x_{t-1}+\cdots \phi_{p} x_{t-p}+\varepsilon_{t}$

\subsection{Johansen Co-Integration Test}

Johansen co-integration test is a VAR model-based test method, but it can be directly used for multivariate co-integration tests. Johansen co-integration likelihood ratio (LR) test:

$H_{0}$ : means there is 0 co-integration relation; $H_{1}$ : means there are $\mathrm{M}$ co-integration relations.

Test statistics: $L R_{M}=-n \sum_{i=M-1}^{N} \log \left(1-\lambda_{i}\right)$. In the equation, $\mathrm{M}$ is the number of cointegrated vectors; $\lambda_{i}$ is the No. $i$ characteristic value arranged in order of size; $n$ is the sample size.

Johansen test is not an independent test that can be completed in one time but a continuous test process targeting different values.EViews starts with testing the null hypothesis that a co-integration relation does not exist, and then at most a co-integration relation. For N-1 co-integration relations, $\mathrm{N}$ times of tests need to be conducted.

\subsection{Model Analysis Procedure}

Based on the Nerlove model, this paper analyzes the influences of rural land circulation on grain security with the analysis procedure as follows: step 1, constructing the Nerlove model of grain output supply response; step 2, selecting variables based on the model; step 3, testing the model, i.e., conducting ADF test and Johansen test of the model; step 4, discussing the test results.

\section{Results and Discussion}

\subsection{Data Sources and Processing}


This paper is based on quantities of literature research as well as real data. The data about grain output, crop sowing area, grain sowing area and effective irrigation area are from the Statistical Yearbook of H Province (2010-2014); the data about the price index of means of agricultural production, grain price index and vegetable price index are from the Rural Statistical Yearbook of H Province (2010-2014); the data about rural land circulation area are from the survey conducted by relevant rural management and administration departments of $\mathrm{H}$ Province.

3.1.1. Model Building: As the Nerlove model supposes that peasant households adjust area (output) according to the expected price to respond to external stimulus, this paper introduces some external variables to quantitatively study the influences of rural land circulation on grain security based on Nerlove model. Land is an essential input factor in agricultural production, and peasant household's production and business decisions are usually that they allocate land areas according to the expected prices of different crops. Meanwhile, grain production is influenced by the effective irrigation area, grain crop sowing area and other factors. Therefore, according to the agricultural product production theory, this paper takes the gross output of grain as a dependent variable and introduces such dependent variables as grain planting area, crop sowing area and land circulation area.

In view of that directly estimating the Nerlove model may result in auto-correlation and approximate multicollinearity existing in arrays, this paper gives logarithmic treatment to each variable to ensure that residual obeys normal distribution and short-term supply elasticity is secured. To inspect the grain supply response of different regions, this paper mainly uses the fixed effect model in the panel data model for demonstration and adopts GLS method to carry out panel data regression to reduce cross-section data heteroscedasticity phenomena.

Therefore, the grain output supply response model in this paper is:

$$
\begin{gathered}
\ln l s z c l_{i, t}=b_{0}+b_{1} \ln l s j g z s_{i, t-1}+b_{2} \ln s c j g z s_{i, t-1}+b_{3} \ln l s b z m j_{i, t}+b_{4} \ln n d l z m j_{i, t}+ \\
b_{5} \ln y x g g m j_{i, t}+\mu_{t}
\end{gathered}
$$

In the equation, $l s z c l_{i, t}$ stands for the grain output in the very term of grain production;

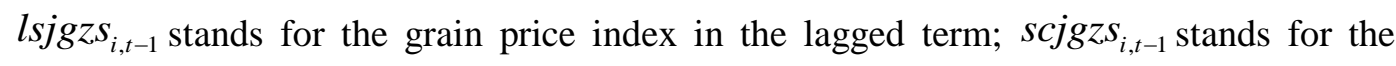
vegetable price index in the lagged term; $\ln l s b z m j_{i, t}$, ln $n d l z m j_{i, t}$ and $y x g g m j_{i, t}$ respectively stand for grain crop sowing area, rural land circulation area and effective irrigation area in the very term of grain production; $\mu_{t}$ stands for random disturbance term, $i$ stands for different regions, and $t$ stands for term.

3.1.2. Variable Selection: As this paper studies the rural land policies from the perspective of grain security, the most basic availability dimension of grain security is selected as a dependent variable, that is, grain output is selected as a dependent variable and the rural land circulation area is selected as an independent variable, and meanwhile other factors influencing grain output are introduced into the paper, such as grain crop sowing area, agricultural effective irrigation area, grain price index and vegetable price index (See Table 1).

Table 1. Variable to Explain and Forecast

\begin{tabular}{ccccc}
\hline $\begin{array}{c}\text { Type of } \\
\text { variable }\end{array}$ & Variable & Code & Definition & $\begin{array}{c}\text { Effect } \\
\text { forecast }\end{array}$ \\
\hline $\begin{array}{c}\text { Dependent } \\
\text { variable }\end{array}$ & $\begin{array}{c}\text { Gross output of } \\
\text { grain }\end{array}$ & $l_{s z c l_{i, t}}$ & $\begin{array}{c}\text { Gross output of grain in the } \\
\text { very year of an individual }\end{array}$ & \\
\hline
\end{tabular}




\begin{tabular}{|c|c|c|c|c|}
\hline $\begin{array}{l}\text { Type of } \\
\text { variable }\end{array}$ & Variable & Code & Definition & $\begin{array}{l}\text { Effect } \\
\text { forecast }\end{array}$ \\
\hline $\begin{array}{l}\text { Explanatory } \\
\text { variable }\end{array}$ & $\begin{array}{l}\text { Grain price } \\
\text { index }\end{array}$ & $\operatorname{lsjgzs}_{i, t-1}$ & $\begin{array}{c}\text { Grain price index in the } \\
\text { lagged term }\end{array}$ & + \\
\hline $\begin{array}{l}\text { Explanatory } \\
\text { variable }\end{array}$ & $\begin{array}{l}\text { Vegetable } \\
\text { price index }\end{array}$ & $s c j g z s_{i, t-1}$ & $\begin{array}{l}\text { Vegetable price index in the } \\
\text { lagged term }\end{array}$ & - \\
\hline $\begin{array}{l}\text { Explanatory } \\
\text { variable }\end{array}$ & $\begin{array}{l}\text { Crop sowing } \\
\text { area }\end{array}$ & $l_{s} b z m j_{i, t}$ & $\begin{array}{l}\text { Supply response reflecting } \\
\text { the scale of grain sowing }\end{array}$ & + \\
\hline $\begin{array}{l}\text { Explanatory } \\
\text { variable }\end{array}$ & $\begin{array}{l}\text { Effective } \\
\text { irrigation area }\end{array}$ & $n d l z m j_{i, t}$ & $\begin{array}{l}\text { Supply response reflecting } \\
\text { the scale of agricultural } \\
\text { effective irrigation }\end{array}$ & + \\
\hline $\begin{array}{l}\text { Explanatory } \\
\text { variable }\end{array}$ & $\begin{array}{l}\text { Total area of } \\
\text { rural land } \\
\text { circulation }\end{array}$ & ${ } x \operatorname{sgmi}_{i, t}$ & $\begin{array}{l}\text { Supply response reflecting } \\
\text { the scale of rural land } \\
\text { circulation }\end{array}$ & \\
\hline
\end{tabular}

3.1.3. Model Testing: Before conducting GLS regression, stationarity test and cointegration test of the collected data are conducted. Stationarity refers to that a random process fluctuates around its mean value graphically. In other words, the variance and mean value of a random process and the value of covariance between two random terms depend on the length and lag of these two terms. They are all constants on time sequence and do not depend on the real time of this variance. In reality, any time series data can be regarded as the results of a random process, but most of these data are non-stationary. However, a non-stationary time series can go through several times of differential conversion, as long as differential conversion is not very often and the real information of original data is not lost. If the data are still not stationary after several times of differential conversion, then the regression may be spurious regression. After the stationarity test is completed, it is needed to adjust whether the impact factors are co-integrated next.

ADF test is completed through three models. First, ADF test starts with a model containing intercept and trend terms, then the model only containing intercept terms is tested, and finally the model containing neither intercept term nor trend term is tested. Only when the test results of the three models cannot refuse the null hypothesis can we regard that the time series is non-stationary; as long as the test results of a model refuse the null hypothesis can we deem that the time series is stationary. Software eviews6.0 is used to conduct ADF test (See the results as shown in Table 2).

Table 2. ADF Unit Root Test Results

\begin{tabular}{|c|c|c|c|c|c|}
\hline Variable & $\begin{array}{c}\text { ADF } \\
\text { statistics }\end{array}$ & $\begin{array}{l}1 \% \text { critical } \\
\text { value }\end{array}$ & $\begin{array}{l}5 \% \text { critical } \\
\text { value }\end{array}$ & $\begin{array}{l}10 \% \text { critical } \\
\text { value }\end{array}$ & Conclusion \\
\hline $\begin{array}{l}\text { Gross output of } \\
\text { grain }\end{array}$ & -8.620731 & -3.546089 & -2.911720 & -2.5935520 & Stationary* \\
\hline $\begin{array}{l}\Delta \text { Gross output of } \\
\text { grain }\end{array}$ & -10.567365 & -3.546089 & -2.911720 & -2.5935520 & Stationary * \\
\hline Grain crop area & -2.89043 & -3.530040 & -2.904838 & -2.5899060 & $\begin{array}{c}\text { Stationary } \\
* * *\end{array}$ \\
\hline$\Delta$ Grain crop area & -13.43215 & -3.530040 & -2.904838 & -2.5899060 & Stationary * \\
\hline $\begin{array}{l}\text { Vegetable price } \\
\text { index }\end{array}$ & -0.984028 & -3.5285140 & -2.904188 & -2.5895630 & $\begin{array}{c}\text { Non- } \\
\text { stationary } \\
* * *\end{array}$ \\
\hline $\begin{array}{l}\Delta \text { Vegetable price } \\
\text { index }\end{array}$ & -8.173767 & -3.530040 & -2.904838 & -2.5899060 & Stationary * \\
\hline $\begin{array}{l}\text { Land circulation } \\
\text { area }\end{array}$ & -2.89054 & -3.530040 & -2.904838 & -2.5899060 & $\begin{array}{l}\text { Stationary } \\
\text { *** }\end{array}$ \\
\hline
\end{tabular}




\begin{tabular}{|c|c|c|c|c|c|}
\hline Variable & $\begin{array}{c}\text { ADF } \\
\text { statistics }\end{array}$ & $\begin{array}{l}1 \% \text { critical } \\
\text { value }\end{array}$ & $\begin{array}{l}5 \% \text { critical } \\
\text { value }\end{array}$ & $\begin{array}{l}10 \% \text { critical } \\
\text { value }\end{array}$ & Conclusion \\
\hline $\begin{array}{c}\Delta \text { Land circulation } \\
\text { area }\end{array}$ & -13.43215 & -3.530040 & -2.904838 & -2.5899060 & Stationary * \\
\hline $\begin{array}{c}\text { Effective irrigation } \\
\text { area }\end{array}$ & -7.893242 & -3.546089 & -2.911720 & -2.5935520 & Stationary * \\
\hline $\begin{array}{c}\Delta \text { Effective } \\
\text { irrigation area }\end{array}$ & -9.327492 & -3.546089 & -2.911720 & -2.5935520 & Stationary * \\
\hline Grain price index & -1.114613 & -3.528514 & -2.904188 & -2.589563 & $\begin{array}{c}\text { Non- } \\
\text { stationary } \\
* * *\end{array}$ \\
\hline$\Delta$ Grain price index & -8.16798 & -3.53004 & -2.904838 & -2.589906 & Stationary $*$ \\
\hline $\begin{array}{l}\text { Note: } \Delta \text { refers to } \\
\text { critical value at the } \\
\text { level of } 10 \% \text {. } \\
\text { As what the co-int } \\
\text { exists between the } \\
\text { explained variables } \\
\text { been conducted abo } \\
\text { Only when they are } \\
\text { conduct a regression } \\
\text { According to the } \\
\text { having no trend ter } \\
\text { determined first. In tl } \\
\text { (SC) are used to de } \\
\text { minimum simultaneo } \\
\text { to conduct an analys } \\
\text { 2. As the unconstrain } \\
\text { Johansen co-integrat } \\
\text { is 1-order. }\end{array}$ & $\begin{array}{l}\text { rst differen } \\
\text { gnificance } \\
\text { gration test } \\
\text { odel varia } \\
\text { same-orde } \\
\text {, so it is } \mathrm{n} \\
\text { me-order in } \\
\text { alysis. } \\
\text { sults of Al } \\
\text { is conduct } \\
\text { paper, Ak: } \\
\text { mine the l} \\
\text { ly in the pr } \\
\text { (See Table } \\
\text { d lag order } \\
\text { n test, the } 1\end{array}$ & $\begin{array}{l}\text { ms to prove } \\
\text { es, the pre } \\
\text { integration } \\
\text { ded to carry } \\
\text { gration can } \\
\text { F test, co-in } \\
\text { d. However, } \\
\text { ke Informati } \\
\text { difference } \\
\text { cess of p-val } \\
\text { and work o } \\
\text { the VAR m } \\
\text { order of the }\end{array}$ & $\begin{array}{l}\text { whether a } \\
\text { ise is that } \\
\text { root unit te } \\
\text { out same-or } \\
\text { directly tak } \\
\text { gration test } \\
\text { before co-in } \\
\text { Criterion ( } \\
\text { ) and make } \\
\text { increasing. } \\
t \text { that the lag } \\
\text { del is } 1 \text { grea } \\
\text { Johansen co }\end{array}$ & $\begin{array}{l}\text { er integratio } \\
\text { difference o } \\
\text { aving interce } \\
\text { gration test, } \\
\text { IC) and Schy } \\
\text { the value of }\end{array}$ & $\begin{array}{l}\text { el of } 1 \%, * * \\
\text { significance } \\
\text { onary relation } \\
\text { ariables and } \\
\text { ADF test has } \\
\text { a conversion. } \\
\text { logarithm to } \\
\text { ept terms but } \\
\text { lag order is } \\
\text { varz Criterion } \\
\text { AIC and SC } \\
\text { ws6.0 is used } \\
\text { AR model is } \\
\text { g order of the } \\
\text { st determined }\end{array}$ \\
\hline
\end{tabular}

Table 3. Unconstrained Lag Order of the VAR Model

\begin{tabular}{ccccccc}
\hline Lag & $\log \mathrm{L}$ & Lr R & FPE & AIC & SC & HQ \\
\hline 1 & 1325988 & 200.8974 & $5.13 \mathrm{E}-06$ & -8.9688 & -8.0382 & -8.5284 \\
$2^{*}$ & 152.2624 & 31.2456 & $5.44 \mathrm{E}-06$ & $-9.3825^{*}$ & -8.5493 & -8.9945 \\
\hline
\end{tabular}

Note: The row marked $*$ refers to the lag orders determined in accordance with the criteria.

After the lag order in the Johansen co-integration test is determined to be 1-order, software eviews6.0 is used to conduct an analysis and obtain the characteristic root tracing test results and the max-eigenvalue test results (See Table 4, and 5).

Table 4. Johansen Characteristic Root Tracing Test Results

\begin{tabular}{ccccc}
\hline $\begin{array}{c}\text { Number of null } \\
\text { hypotheses and co- } \\
\text { integration } \\
\text { equations }\end{array}$ & $\begin{array}{c}\text { Characteristic } \\
\text { value }\end{array}$ & $\begin{array}{c}\text { Characteristic } \\
\text { root tracing } \\
\text { statistics }\end{array}$ & $\begin{array}{c}\text { Critical value at } \\
\text { the significance } \\
\text { level of } 5 \%\end{array}$ & P-value \\
\hline Zero* & 0.13420 & 3.380528 & 15.49472 & 0.0004 \\
At most 1 & 0.000362 & 0.010108 & 3.841467 & 0.9196 \\
\hline
\end{tabular}

Johansen characteristic root tracing test results indicate that 1 co-integration relationship exists between such six variables as gross output of grain, grain crop sowing 
area, land circulation area, effective irrigation area, grain price index and vegetable price index at the significance level of $5 \%$.

Table 5. Johansen Maximum Characteristic Value Test Results

\begin{tabular}{ccccc}
\hline $\begin{array}{c}\text { Number of null } \\
\text { hypotheses and co- } \\
\text { integration } \\
\text { equations }\end{array}$ & $\begin{array}{c}\text { Characteristic } \\
\text { value }\end{array}$ & $\begin{array}{c}\text { Characteristic } \\
\text { root tracing } \\
\text { statistics }\end{array}$ & $\begin{array}{c}\text { Critical value at } \\
\text { the significance } \\
\text { level of 5\% }\end{array}$ & P-value \\
\hline Zero* & 0.113420 & 3.370420 & 14.26462 & 0.0006 \\
At most 1 & 0.000362 & 0.010108 & 3.841467 & 0.9238 \\
\hline
\end{tabular}

Note: * stands for refusing the null hypothesis at the significance level of $5 \%$

The Johansen maximum characteristic value test results indicate that there is a longterm stationary relation and a co-integration relationship between the variables that have gone through the logarithm process. In other words, the GLS of these variables is real meaningful regression but not spurious regression.

\subsection{Discussion}

Based on the grain supply response of different regions in H Province, the fixed effect model in the panel data model and GLS method are adopted to conduct regression in this paper. See Table 6, for the eviews 6.0 results.

Table 6. Grain Supply Response GLS Estimation Results

\begin{tabular}{|c|c|c|c|c|c|}
\hline Variable & Code & Coefficient & $\begin{array}{c}\text { Standard } \\
\text { error }\end{array}$ & T statistics & P-value \\
\hline Intercept term & $\mathrm{C}$ & 4.670301 & $\begin{array}{l}0.941906 \\
5.520475\end{array}$ & 0.0000 & Intercept term \\
\hline $\begin{array}{l}\text { Grain price } \\
\text { index }\end{array}$ & $\ln l s j g z s_{i, t-1}$ & 0.050218 & 0.012013 & 6.539428 & Grain price index \\
\hline $\begin{array}{l}\text { Vegetable } \\
\text { price index }\end{array}$ & $\ln s c j g z s_{i, t-1}$ & -0.000014 & 0.000008 & 1.112837 & $\begin{array}{l}\text { Vegetable price } \\
\text { index }\end{array}$ \\
\hline $\begin{array}{c}\text { Grain sowing } \\
\text { area }\end{array}$ & $\ln l s b z m j_{i, t}$ & 0.040607 & 0.001726 & 0.890468 & Grain sowing area \\
\hline $\begin{array}{c}\text { Effective } \\
\text { irrigation area }\end{array}$ & $\ln n d l z m j_{i, t}$ & 0.016425 & 0.000781 & -3.53497 & $\begin{array}{c}\text { Effective } \\
\text { irrigation area }\end{array}$ \\
\hline $\begin{array}{l}\text { Total area of } \\
\text { rural land } \\
\text { circulation }\end{array}$ & $\ln y x g g m j_{i, t}$ & -0.027722 & 0.003417 & 1.705965 & $\begin{array}{l}\text { Total area of rural } \\
\text { land circulation }\end{array}$ \\
\hline
\end{tabular}

The analysis results show that the model's $R^{2}=0.998952$, the adjusted $R^{2}=0.997692$, and $F=267$. 69. It can be seen that all statistics are significant and the model fitting degree is very good. According to the quantitative analysis results, the features of grain supply response can be summarized as follows:

First, a positive correlation exists between grain crop sowing area, effective irrigation area and grain output. It can be seen from the computation results that grain sowing area has a great influence on grain output. Therefore, to ensure grain security, we should stick to the 1.8 billion-mu-red line of farmland area decided by the state and strictly control the grain planting area. As effective irrigation has enhanced the grain's ability to resist natural risks, when droughts or water logging disasters happen, we can ensure that the per unit output of grain will not decrease and will prevent farmers from completely depending on the weather, which helps to guarantee grain security. 
Second, a positive correlation exists between grain price index and grain output and a negative correlation exists between vegetable price index and grain output. Peasant households usually allocate grain crop planting areas according to the profits of crops. Vegetable, as a kind of commercial crop, is equivalent to the opportunity cost of graingrowing, thus, when the profit of commercial crop in the lagged term is high, peasant households would make decisions based on the expected prices.

Third, a negative correlation exists between total area of rural land circulation and per unit area yield of grain. According to the results in Table 6, it seems that a negative correlation exists between total area of rural land circulation and gross output of grain, but the conclusion is not exactly so after in-depth analysis. In the grain supply response model, the dependent variable is the gross output of grain, and independent variables include grain sowing area, rural land circulation area and other variables. As the gross output of grain equal the product of the grain sowing area times the per unit area yield of grain, the coefficient before the rural land circulation area variable actually reflects the influences of rural land circulation area on per unit area yield of grain. In the model, the coefficient of rural land circulation area is -0.027722 , indicating that if the rural land circulation area increases by $1 \%$, the per unit area yield of grain will decrease by $0.027722 \%$. Therefore, if rural land circulation area is increased and operation scale is enlarged, peasant households will determine grain production input according to income maximization. This is different from peasant household's operational decision of selfsufficiency, as the latter is determined by output maximization. Thus, increase in the rural land circulation area may lead to decrease in the per unit area yield of grain.

Grain sowing area is one of the important factors influencing gross output of grain. On the one hand, increase in rural land circulation area enables desolated rural land to be utilized effectively, thus helping increase in grain sowing area; on the other hand, "nongrain farmland phenomenon" and "non-agricultural farmland phenomenon" in rural land circulation will lower the grain sowing area. Non-agricultural farmland phenomenon can be prohibited through implementation of policies, and non-grain farmland phenomenon can be guided though the direct food subsidy policy. Pei Dongxin and Zhang Dongping [12] propose that we should center on the business needs of "large-scale grain production" overall process and systematically improve supportive policies. Policy design should finally achieve the aim of guaranteeing grain production and grain security through the rural land circulation system.

\section{Conclusion}

The author has conducted an empirical survey on the influences of rural land circulation on grain security through constructing Nerlove model. In terms of the negative influences of rural land circulation on grain security, the author deems that we should improve the rural land circulation system from the following aspects to guarantee national grain security:

Firstly, specifying farmer's land property rights. Although various kinds of laws, administrative regulations and documents of the CPC Central Committee require that we should ensure farmer's land property rights, and the decision of "ensure permanency of farmer's contractual right of land" was made at the Third Plenary Session of the 17th CPC Central Committee, actually farmer's land property rights are not stable, and forced or semi-forced circulation, regular or irregular adjustment, arbitrary expropriation and other behaviors harming farmer's land rights often happen. It can be known from the above analysis that rural collective and land circulation usually tends to change the original land use and engages in high value-added facility agriculture, while independent free circulation between peasant households tends to maintain the original land use because of dispersion and small size of land as well as farmer's consideration of future life. Therefore, we should guarantee complete farmer's land property rights to ensure grain security and prevent rural collectives from intervening in farmer's land property rights 
from the perspective of systems. In addition, ensuring farmer's land property rights is conducive to stabilizing farmer's benefit expectation and facilitating accelerated circulation of land. At present, we should turn the documents of the CPC Central Committee into law as early as possible, i.e., revising the Land Management Law. Moreover, we should do well such groundwork as right confirmation and registration of rural land, certificate issuing etc to perfect the farmer's land property rights procedurally.

Secondly, continuously innovating in land circulation models. With the acceleration of China's economic development, urbanization and industrialization, traditional household contract responsibility system with remuneration linked to output has exposed some disadvantages, such as desolated, idle and wasted rural land resources. To realize optimized allocation of rural land resources and increase grain output, China has conducted experiments on rural land circulation. For the special national condition that China has a large population with relatively little land and the traditional factor that the land features high-degree fragmentation, land circulation models have presented some drawbacks, for example, scale operation with large-area land connected and forced circulation going against farmer's will may increase farmer's risks. Therefore, to ensure national grain security, we should adjust measures to local conditions and continuously innovate in rural land circulation models. Rural land circulation should follow four most basic principles: first, observing strictly national laws and regulations; second, respecting farmer's will; third, strictly controlling land use; fourth, balancing risks and benefits. Hence, China's innovation in the land circulation system can boost its innovation in rural land circulation models through legislation perfecting, institutional innovation, organizational innovation, policy support and other ways.

Thirdly, normalizing the behaviors of rural collectives and local governments. Undeniably, as China has a specific land property right system and an administrative management system, rural collectives and local governments play an important role in rural land circulation. How to stem the impulsion of rural collectives and local governments in non-grain-based land circulation? First of all, administratively, superior governments should require local governments and rural collectives to implement the "chief executive responsibility system" like the CPC Central Committee dose on grain and require them to ensure that the amount of arable land in their respective regions will not decrease, use of arable land will not change, quality of arable land will not degrade and grain output will not reduce. Additionally, local officials' work performance should be strictly assessed and linked up with promotion. Moreover, economically, we should change the situation of "large regions in grain output and poor regions in finance". In other words, breadbaskets should not suffer losses in fiscal revenue, and the central government and provincial governments should continue increasing financial transfer payment to breadbaskets so as to truly stem the economic interest motive of local governments and rural collectives for carrying out non-grain-based land circulation.

\section{References}

[1] O. Jian, "Research on the Land Circulation Based on the Visual Angle of Food Security in Main Grain Product Areas of Henan", Journal of North China University of Water Resources and Electric Power(Social Science Edition), vol. 30, no. 5, (2014), pp. 62-66.

[2] G. Feder and D. Feeny, "Land Tenure and Property Rights: Theory and Implications for Development Policy, World Bank Economic Review”, Oxford University Press, vol. 5, no. 1, (1991), pp.135-153.

[3] E. Brabec and C. Smith, "Agricultural Land Fragmentation: the Spatial Effects of Three Land Protection Strategies in the Eastern", United States, vol. 58, (2002), pp. 21-30.

[4] Macmilian, "Information and the Operation of Markets: Tests Based on a General Equilibrium Model of Land Leasing in India", The Journal of Development Economics, vol. 60, no. 2, (1999), pp. 497-528.

[5] Pardey, "Research Productivity and Output Growth in Chinese Agriculture", Journal of Development Economics, vol. 53, (1997), pp. 115-137.

[6] A. Alvarez and C. Arias, "Technical efficiency and farm size: a condition analysis", Agricultural Economies, vol. 30, no. 3, (2004), pp. 241-250. 
[7] Z. Yunhua, Y. Xiaoyan and W. Zhenjun, "Main problems and policy suggestions in the transfer of rural land contract management right", Proceedings of the China land society Conference, Beijing, China, (2010) October, pp. 85-87.

[8] N. Liangpeng, N. Tangyuan and C. Chuanjun, "Land Circulation impact on food security and countermeasures", Journal of Shandong Agricultural University(Social Science Edition), vol. 2, (2013), pp. 65-70.

[9] Z. Zhonggui, "Study on the negative effects of land transfer on food security and measures", Nan Fang Nong Cun, vol. 2, (2010), pp. 55-57.

[10] Z. Wugang, "Study on the tendency and Countermeasures of "non food" in the land transfer in China"Journal of Huanghe Science and Technology College, vol. 5, (2010), pp. 60-63.

[11] M. Nerlove, Bacheman K L, "The Analysis of Changes in Agricultural Supply:Problems and Approaches", Journal of Farm Economics, vol. 42, no. 3, (1960), pp. 20-34.

[12] P. Dongxin and Z. Dongping, "Consideration on promoting the stable production of Henan under the background of land Circulation”, Hong Guan Jing Ji Guan Li, vol. 6, (2015), pp. 70-73.

\section{Authors}
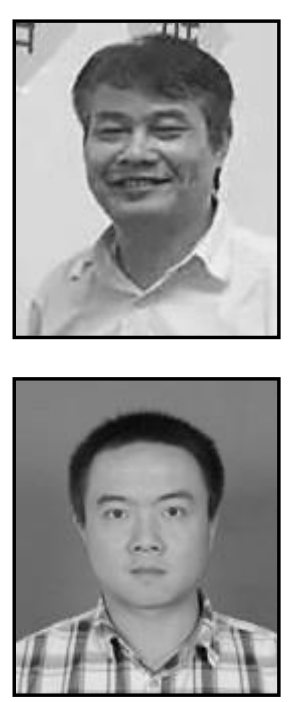

Xu Jiajun, he was born in 1966, native of Huaian City, Jiangsu Province, Professor of Hohai Uinversity, main research areas of immigration sociology, political science, administration.

Wang Mingzhe, he was born in 1988, native of Xinxiang City, Henan Province Hohai University Ph.D., principal research areas of urban and rural sociology, Sociology of Immigration and Game Theory. 